\title{
GAMBARAN TINGKAT KEPUASAN PASIEN PADA PELAYANAN RAWAT JALAN, RAWAT INAP DAN RUANG OPERASI DI RUMAH SAKIT PERTAMINA BINTANG AMIN BANDAR LAMPUNG TAHUN 2018
}

\author{
Ade Utia Detty ${ }^{1}$ \\ ${ }^{1}$ Departemen Imunologi, Fakultas Kedokteran Universitas Malahayati
}

\begin{abstract}
The Analysis Of Patients' Satisfaction On The Service of Outpatient, Inpatient, And Surgery Room In Pertamina Bintang Amir Hospital Bandar Lampung 2018. Health service quality showed to be categorized in perfect level in terms of health service in emerging self satisfaction on every patient. The percentage of inpatient patients' satisfaction of Pertamina Bintang Amin Hospital Bandar Lampung was assessed internally in 2017, obtaining value of $75 \%$. This value is still below the indicator of Minimum Service Standard (SPM) of inpatient which is $90 \%$. The purpose of this research was to know the patients' satisfaction level on the service of inpatient, outpatient and surgery room in Bintang Amin Hospital Bandar Lampung in 2018. This research was quantitative research through cross sectional research type. Sampling was done through purposive sampling technique based on the criteria needed by the researcher. The data were collected using questionnaire distributed to the respondents. The research has been performed on May 2018 in which the data analysis was done in univariate manner. Based on the research result, it was known that there was difference on patients' satisfaction in inpatient unit and surgery room unit which is $48.6 \%$ in inpatient unit and $54.3 \%$ in surgery room. It can be concluded from the three rooms that the inpatient unit is the unit having the lowest patients' satisfaction compared to the outpatient and surgery rooms units. In the outpatient unit, the empathy aspect is not really good which is $61 \%$. In the inpatient unit, the insurance and response is not really good, which is $50 \%$. Meanwhile, in the surgery room, the empathy and response is also not really good which is $56.2 \%$. Suggestion to remind the service and fastness performance of the nursery staff and doctor is by conducting training and briefing periodically. Skill test which is related to the operational service and training to increase the empathy towards the patient is also needed.
\end{abstract}

Keywords: Patient, Satisfaction Level, Service

\begin{abstract}
Abstrak: Analisis Tingkat Kepuasan Pasien Pada Pelayanan Rawat Jalan, Rawat Inap Dan Ruang Operasi Di Rumah Sakit Pertamina Bintang Amin Bandar Lampung Tahun 2018. Mutu pelayanan kesehatan menunjukkan pada tingkat kesempurnaan pelayanan kesehatan dalam menimbulkan rasa puas pada diri setiap pasien. Persentase kepuasan pasien rawat inap Rumah Sakit Pertamina Bintang Amin (RSPBA) Bandar Lampung yang juga dinilai secara intenal pada tahun 2017, yaitu 75\%. Nilai ini juga masih berada di bawah dari indikator Standar Pelayanan Minimal (SPM) rawat inap, yaitu 90\%. Tujuan dari penelitian diketahui tingkat kepuasan pasien pada pelayanan rawat jalan, rawat inap dan ruang Operasi di RS Bintang Amin Bandar Lampung tahun 2018. Penelitian ini merupakan penelitian kuantitatif, dengan jenis penelitian cross sectional. Pengambilan sampel secara purposive sampling yaitu berdasarkan kriteria yang diinginkan oleh peneliti. Pengambilan data menggunakan kuesioner yang dibagikan ke responden. Penelitian telah dilakukan bulan Mei 2018. Analisis data secara univariat. Hasil penelitian diketahui perbedaan kepuasan pada pasien di unit rawat inap sebesar $48.6 \%$ puas
\end{abstract}


dan di unit rawat inap serta di kamar operasi masing-masing sebesar $54.3 \%$ puas. dapat disimpulkan bahwa dari ketiga ruangan tersebut, unit rawat inap merupakan unit dengan kepuasan pasien terendah jika dibandingkan dengan unit rawat jalan dan kamar operasi, di unit rawat jalan aspek empati kurang baik sebesar $61 \%$, pada unit rawat inap jaminan dan daya tangap kurang baik sebesar $50 . \%$ dan unit kamar operasi empati dan daya tangap kurang baik sebesar $56.2 \%$. Saran untuk meningkatkan kinerja dan kecepatan layanan tenaga perawatan dan dokter maka perlu dilakukan pelatihan serta briefing secara berkala, serta melakukan skill test yang berhubungan dengan operasional pelayanan serta mengadakan pelatihan untuk meningkatkan rasa empati terhadap pasien.

Kata kunci : Pasien, Pelayanan, Tingkat kepuasan

\section{PENDAHULUAN}

Jaminan mutu pelayanan kesehatan sebagai salah satu kiat manajemen akan memberikan berbagai manfaat bagi manajemen pelayanan kesehatan, baik yang menyangkut organisasi, perencanaan ataupun penyelenggaraan layanan kesehatan itu sendiri. Oleh karena itu, setiap pemberi layanan kesehatan yang secara langsung melayani pasien perlu memiliki keterampilan jaminan mutu layanan kesehatan (Pohan, 2013).

Dengan memperhatikan mutu, berarti kita telah membantu pasien untuk mendapatkan hasil layanan kesehatan terbaik sehingga memberikan tanggapan yang tepat dan kepedulian yang layak terhadap setiap kebutuhan manusia yang sedang menghadapi musibah. Pembahasan mutu layanan kesehatan sering terpusat pada kepuasan pasien atau konsumen, standar profesi, dan audit klinis (Nursalam, 2016).

Mutu pelayanan kesehatan
menunjukkan kesempurnaan pelayanan kesehatan dalam menimbulkan rasa puas pada diri setiap pasien. Makin sempurna kepuasan tersebut maka makin baik pula mutu pelayanan kesehatan. Kepuasan pasien adalah suatu tingkat perasaan pasien yang timbul sebagai akibat dari kinerja layanan kesehatan yang diperoleh setelah pasien membandingkannya dengan apa yang diharapkan (Pohan, 2013).

Kepuasan merupakan perasaan seseorang mengenai kesenangan atau kekecewaan sebagai hasil perbandingan antara kinerja dan harapan. Apabila kinerja yang diterima di bawah harapan mereka, maka pasien merasa tidak puas. Apabila kinerja sesuai atau melebihi harapan maka pasien akan merasa puas. Pengalaman jasa kesehatan sebelumnya penting untuk menentukan evaluasi penggunaan pelayanan kesehatan yang sama dimasa yang akan datang. Pengalaman tersebut akan mempengaruhi harapan pasien untuk memperoleh pelayanan yang sama (Tjiptono, 2015).

Jumlah rumah sakit di Indonesia sebanyak 2.488 RS dengan berbagai tipe pengurus, sedangkan jumlah rumah sakit tipe $C$ sendiri berjumlah 837" (Profil Kesehatan Indonesia, 2015). Untuk Kota Bandar Lampung jumlah rumah sakit adalah sebanyak 17 , sedangkan jumlah rumah sakit tipe $C$ sendiri adalah berjumlah 7 rumah sakit (Profil Kesehatan Kota Bandar Lampung, 2014).

Dari 7 rumah sakit tipe $C$ di Bandar Lampung, peneliti menganalisis rumah sakit di Bandar Lampung yang telah terakreditasi paripurna berdasarkan penilaian Komite Akreditasi Rumah Sakit (KARS) 2012, salah satunya yaitu Rumah Sakit Pertamina Bintang Amin (RSPBA). Persentase kepuasan pasien rawat inap Rumah Sakit Pertamina Bintang Amin (RSPBA) Bandar Lampung yang juga dinilai secara internal pada tahun 2017, yaitu $75 \%$. Nilai ini juga masih berada di bawah dari indikator Standar Pelayanan Minimal (SPM) rawat inap, yaitu $90 \%$. Penelitian ini mengambil sampel di RS 
Pertamina Bintang Amin yang merupakan salah satu RS bertipe C di Bandar Lampung. RS ini juga menampung pelayanan rujukan dari Fasilitas kesehatan tingkat pertama.

Berdasarkan data yang peneliti dapat dari bagian Humas RS Pertamina Bintang Amin didapatkan, tingkat kepuasan pasien sebesar $75 \%$, pemanfaatan tempat tidur yaitu BOR rumah sakit yang berfluktuasi dengan nilai rata-rata $55 \%$ artinya masih di bawah standar dari nilai normal 60-80 $\%$ sehingga menyebabkan mutu efisiensi masih kurang optimal, serta indikator pelayanan rumah sakit yaitu Average length of stay (ALOS) dengan rata rata lama hari rawat Nilai standar 6-9 hari, dan jauh berbeda dengan perawatan yang ada di Rumah Sakit masih di bawah standar ideal yaitu 3-4 hari sehingga dapat menggambarkan mutu pelayanan masih belum optimal. Sedangkan berdasarkan Kepmenkes No 129 tentang standar pelayanan minimal rumah sakit, pada unit rawat inap kepuasan pasien dengan indikator $\geq 90 \%$. Hal tersebut dapat menunjukkan bahwa kualitas pelayanan belum mencapai standar SPM atau masih rendah (Rumah Sakit Bintang Amin Bandar Lampung , 2017).

Hasil pengamatan peneliti selama melakukan studi pendahuluan di ruang rawat inap RS Pertamina Bintang Amin, dijumpai adanya pasien yang menyatakan kurang puas dengan pelayanan dilakukan di RS Pertamina Bintang Amin, dari tahun 2016-207 didapatkan dari SMS Center total jumlah pasien yang memberikan nilai puas untuk pelayanan di rumah Sakit Pertamina Bintang Amin adalah sebesar $45 \%$, sisanya sebesar $55 \%$ mengeluhkan tentang pelayanan yang kurang memuaskan. Diketahui juga jumlah komplain terbanyak dengan urutan pertama adalah di ruang rawat inap sebesar $40 \%$, kamar operasi $22 \%$, rawat jalan $30 \%$, sisanya adalah keluhan di instalasi atau unit kerja yang lain. Masing-masing keluhan dirawat inap adalah pelayanan keperawatan, jam visit dokter, komunikasi yang tidak tersampaikan dengan baik oleh perawat, pasien merasa perawat tidak ramah dan merasa tidak diperhatikan. Di kamar operasi yang dikeluhkan adalah seringnya pembatalan operasi dengan alasan yang tidak sesuai dengan kontra indikasi medis pasien, juga jam waktu operasi yang sering tidak tepat waktu. Di rawat jalan adalah lamanya antrian pada loket pendaftaran (RSPBA tahun 2017).

\section{METODE}

Penelitian ini merupakan penelitian kuantitatif, dengan jenis penelitian cros sectional. Diketahui tingkat kepuasan pasien saat di rawat jalan, rawat inap dan ruang operasi di Rumah Sakit Pertamina Bintang Amin Bandar Lampung. Pengambilan sampel secara purposive sampling yaitu berdasarkan kriteria yang diinginkan oleh peneliti. Pengambilan data menggunakan kuesioner yang dibagikan ke responden. Penelitian telah dilakukan bulan Mei 2018.

\section{HASIL DAN PEMBAHASAN}

\section{Hasil Penelitian}

\section{Karakteristik Responden}

Berdasarkan tabel 1. di bawah menunjukkan distribusi frekuensi karakteristik responden berdasarkan jenis kelamin dari 105 responden di RSPBA yang diteliti terdiri dari perempuan $64(61,0 \%)$ responden dan laki-laki $41 \quad(39,0 \%)$ responden. Distribusi frekuensi karakteristik responden RSPBA berdasarkan usia dari 105 responden yang paling banyak jumlahnya adalah usia 41-50 berjumlah $33(31,4 \%)$ responden dan yang paling sedikit adalah usia di atas 60 tahun jumlahnya $5 \quad(4,8 \%)$ responden.

Distribusi frekuensi karakteristik responden RSPBA berdasarkan pendidikan dari 105 responden yang paling banyak jumlahnya adalah tamat SMP berjumlah $39(37,1 \%)$ responden dan yang paling sedikit adalah tamat akademi/perguruan jumlahnya 10 $(9,5 \%)$ responden. Distribusi frekuensi karakteristik responden berdasarkan 
pekerjaan dari 105 responden yang

paling sedikit adalah TNI/POLRI $(1,9 \%)$ responden.

paling banyak jumlahnya adalah Ibu

Rumah Tangga $30(28,6 \%)$ dan yang

Tabel 1. Distribusi Frekuensi Karakteristik Responden

\begin{tabular}{|c|c|c|c|}
\hline Variabel & Kategori & Jumlah & $\begin{array}{c}\text { Persentase } \\
(\%)\end{array}$ \\
\hline \multirow{2}{*}{ Jenis Kelamin } & Laki-laki & 41 & 39 \\
\hline & Perempuan & 64 & 61 \\
\hline \multirow{5}{*}{$\begin{array}{c}\text { Usia } \\
\text { (tahun) }\end{array}$} & $18-30$ & 26 & 24.8 \\
\hline & $31-40$ & 20 & 19.0 \\
\hline & $41-50$ & 33 & 31.4 \\
\hline & $51-60$ & 21 & 20.0 \\
\hline & $>60$ & 5 & 4.8 \\
\hline \multirow{5}{*}{ Pendidikan } & Kurang tamat SD & 7 & 6.7 \\
\hline & SD & 19 & 18.1 \\
\hline & SMP & 39 & 37.1 \\
\hline & SMA & 30 & 28.6 \\
\hline & Akademi/Perguruan & 10 & 9.5 \\
\hline \multirow{10}{*}{ Pekerjaan } & Petani & 12 & 11.4 \\
\hline & Buruh & 12 & 11.4 \\
\hline & Pertukangan & 4 & 3.8 \\
\hline & PNS & 5 & 4.8 \\
\hline & TNI/POLRI & 2 & 1.9 \\
\hline & Swasta & 17 & 16.2 \\
\hline & Wirausaha & 20 & 19.0 \\
\hline & Pensiunan & 3 & 2.9 \\
\hline & Ibu Rumah Tangga & 20 & 28.6 \\
\hline & Total & 105 & 100 \\
\hline
\end{tabular}

2. Gambaran Kepuasan Pasien Di Ruang Rawat Jalan RS Pertamina Bintang Amin.

Berdasarkan tabel 2, diketahui bahwa dari kelima mutu pelayanan di unit rawat jalan, terlihat bahwa sebagian besar responden mengungkapkan kehandalan kurang baik yaitu sebanyak $59 \%$, jaminan kurang baik sebesar $58.1 \%$, bukti fisik baik sebanyak $59 \%$, empati kurang baik sebanyak $61 \%$ dan daya tanggap kurang baik sebanyak 54.3\%. berdasarkan tabel di bawah dapat disimpulkan bahwa dari kelima dimensi yang berkaitan dengan kepuasan tersebut diketahui bahwa aspek empati merupakan aspek yang paling banyak dengan kategori kurang baik.
Kepuasan responden terhadap pelayanan diruang rawat jalan RS Pertamina Bintang Amin berdasarkan lima dimensi mutu berdasarkan tabel 2, di bawah diketahui rata-rata kepuasan pasien rawat jalan pada Kehandalan adalah 12.00 dengan nilai kepuasan minimal 6 dan maksimal 20,0 . Pada Jaminan adalah 12.93 dengan nilai kepuasan minimal 8 dan maksimal 20,0. Pada Bukti fisik adalah 11,87 dengan nilai kepuasan minimal 6 dan maksimal 18. Pada Empati adalah 12.78 dengan nilai kepuasan minimal 8 dan maksimal 20,0. Pada daya tanggap adalah 12.88 dengan nilai kepuasan minimal 8 dan maksimal 20,0. 
Tabel 2. Gambaran Kepuasan Pasien di Ruang Rawat Jalan RS. Pertamina Bintang Amin Tahun 2018

\begin{tabular}{|c|c|c|c|c|c|c|c|}
\hline Variabel & Kategori & Frekuensi & $\begin{array}{c}\text { Persentase } \\
(\%)\end{array}$ & Mean & SD & Min & $\operatorname{Max}$ \\
\hline \multirow{2}{*}{ Kehandalan } & Baik & 43 & 41.0 & \multirow{2}{*}{12.00} & \multirow{2}{*}{3.742} & \multirow{2}{*}{6} & \multirow{2}{*}{20} \\
\hline & Kurang Baik & 62 & 59.0 & & & & \\
\hline \multirow{2}{*}{ Jaminan } & Baik & 44 & 41.9 & \multirow{2}{*}{12.93} & \multirow{2}{*}{3.126} & \multirow{2}{*}{8} & \multirow{2}{*}{20} \\
\hline & Kurang Baik & 61 & 58.1 & & & & \\
\hline \multirow{2}{*}{ Bukti fisik } & Baik & 62 & 59.0 & \multirow{2}{*}{11.87} & \multirow{2}{*}{3.533} & \multirow{2}{*}{6} & \multirow{2}{*}{18} \\
\hline & Kurang Baik & 43 & 41.0 & & & & \\
\hline \multirow{2}{*}{ Empati } & Baik & 41 & 39.0 & \multirow{2}{*}{12.78} & \multirow{2}{*}{3.032} & \multirow{2}{*}{8} & \multirow{2}{*}{20} \\
\hline & Kurang Baik & 64 & 61.0 & & & & \\
\hline \multirow{2}{*}{$\begin{array}{c}\text { Daya } \\
\text { tanggap }\end{array}$} & Baik & 48 & 45.7 & \multirow{2}{*}{12.88} & \multirow{2}{*}{3.474} & \multirow{2}{*}{8} & \multirow{3}{*}{20} \\
\hline & Kurang Baik & 57 & 54.3 & & & & \\
\hline & & 105 & 100 & & & & \\
\hline
\end{tabular}

\section{Gambaran Kepuasan Pasien Di Ruang Rawat Inap RS Pertamina Bintang Amin}

Berdasarkan tabel 3 di bawah diketahui rata-rata kepuasan pasien rawat inap pada Kehandalan adalah 12.07 dengan nilai kepuasan minimal 5 dan maksimal 20,0. Pada Jaminan adalah 11.86 dengan nilai kepuasan minimal 5 dan maksimal 20,0. Pada Bukti fisik adalah 13.24 dengan nilai kepuasan minimal 6 dan maksimal 20. Pada empati adalah 12.12 dengan nilai kepuasan minimal 5 dan maksimal 20,0 . Pada daya tanggap adalah 12.42 dengan nilai kepuasan minimal 8 dan maksimal 20,0.

Berdasarkan tabel 3, diketahui bahwa dari kelima mutu pelayanan di unit rawat inap, terlihat bahwa sebagian besar responden mengungkapkan kehandalan baik yaitu sebanyak $51.4 \%$, jaminan kurang baik sebesar $50.5 \%$, bukti fisik baik sebanyak 56.2\%, empati baik sebanyak $51.4 \%$ dan daya tanggap kurang baik sebanyak $50.5 \%$. berdasarkan table diatas dapat disimpulkan bahwa dari kelima dimensi yang berkaitan dengan adalah 7,95 dengan nilai kepuasan minimal 3 dan maksimal 12. Pada Empati adalah 8,00 dengan nilai kepuasan minimal 4 dan maksimal 12. kepuasan tersebut diketahui bahwa aspek jaminan dan daya tangap merupakan aspek yang paling banyak dengan kategori kurang baik.

\section{Gambaran Kepuasan Pasien Di Ruang Operasi RS Pertamina Bintang Amin}

Berdasarkan tabel 4, diketahui bahwa dari kelima mutu pelayanan di unit kamar operasi, terlihat bahwa sebagian besar responden mengungkapkan kehandalan baik yaitu sebanyak $58.1 \%$, jaminan baik sebesar $62.9 \%$, bukti fisik baik sebanyak $65.7 \%$, empati kurang baik sebanyak $56.2 \%$ dan daya tanggap kurang baik sebanyak $56.2 \%$. Berdasarkan tabel di bawah dapat disimpulkan bahwa dari kelima dimensi yang berkaitan dengan kepuasan tersebut diketahui bahwa aspek empati dan daya tangap di unit kamar operasi kategori kurang baik.

Berdasarkan tabel 4 di bawah diketahui rata-rata kepuasan pasien kamar operasi pada Kehandalan adalah 8.18 dengan nilai kepuasan minimal 3 dan maksimal 12. Pada Jaminan adalah 9,18 dengan nilai kepuasan minimal 4 dan maksimal 16,0. Pada Bukti fisik Pada daya tanggap adalah 8,11 dengan nilai kepuasan minimal 3 dan maksimal 12. 
Tabel 3. Gambaran Kepuasan Pasien di Ruang Rawat Inap RS. Pertamina Bintang Amin Tahun 2018

\begin{tabular}{|c|c|c|c|c|c|c|c|}
\hline Variabel & Kategori & Frekuensi & $\begin{array}{c}\text { Persentase } \\
(\%)\end{array}$ & Mean & SD & Min & Max \\
\hline \multirow{2}{*}{ Kehandalan } & Baik & 54 & 54.0 & \multirow{2}{*}{12.07} & \multirow{2}{*}{3.947} & \multirow{2}{*}{5} & \multirow{2}{*}{20} \\
\hline & Kurang Baik & 51 & 51.0 & & & & \\
\hline \multirow{2}{*}{ Jaminan } & Baik & 52 & 52.0 & \multirow{2}{*}{11.86} & \multirow{2}{*}{3.471} & \multirow{2}{*}{5} & \multirow{2}{*}{20} \\
\hline & Kurang Baik & 53 & 53.0 & & & & \\
\hline \multirow{2}{*}{ Bukti fisik } & Baik & 59 & 59.0 & \multirow{2}{*}{13.24} & \multirow{2}{*}{3.081} & \multirow{2}{*}{6} & \multirow{2}{*}{18} \\
\hline & Kurang Baik & 46 & 46.0 & & & & \\
\hline \multirow{2}{*}{ Empati } & Baik & 54 & 54.0 & \multirow{2}{*}{12.12} & \multirow{2}{*}{3.290} & \multirow{2}{*}{5} & \multirow{2}{*}{20} \\
\hline & Kurang Baik & 51 & 51.0 & & & & \\
\hline \multirow{2}{*}{$\begin{array}{c}\text { Daya } \\
\text { tanggap }\end{array}$} & Baik & 52 & 52.0 & \multirow{2}{*}{12.42} & \multirow{2}{*}{3.034} & \multirow{2}{*}{5} & \multirow{2}{*}{20} \\
\hline & Kurang Baik & 53 & 53.0 & & & & \\
\hline \multicolumn{2}{|c|}{ Total } & 105 & & & & & \\
\hline
\end{tabular}

Tabel 4. Gambaran Kepuasan Pasien di Ruang Operasi RS. Pertamina Bintang Amin Tahun 2018

\begin{tabular}{|c|c|c|c|c|c|c|c|}
\hline Variabel & Kategori & Frekuensi & $\begin{array}{c}\text { Persentase } \\
(\%)\end{array}$ & Mean & SD & Min & Max \\
\hline \multirow{2}{*}{ Kehandalan } & Baik & 61 & 58.1 & \multirow{2}{*}{8.18} & \multirow{2}{*}{2.727} & \multirow{2}{*}{3} & \multirow{2}{*}{12} \\
\hline & Kurang Baik & 44 & 41.9 & & & & \\
\hline \multirow{2}{*}{ Jaminan } & Baik & 66 & 62.9 & \multirow{2}{*}{9.18} & \multirow{2}{*}{3.172} & \multirow{2}{*}{4} & \multirow{2}{*}{16} \\
\hline & Kurang Baik & 39 & 37.1 & & & & \\
\hline \multirow{2}{*}{ Bukti fisik } & Baik & 69 & 65.7 & \multirow{2}{*}{7.95} & \multirow{2}{*}{1.389} & \multirow{2}{*}{3} & \multirow{2}{*}{12} \\
\hline & Kurang Baik & 36 & 34.3 & & & & \\
\hline \multirow{2}{*}{ Empati } & Baik & 46 & 43.8 & \multirow{2}{*}{8.00} & \multirow{2}{*}{1.352} & \multirow{2}{*}{4} & \multirow[t]{2}{*}{12} \\
\hline & Kurang Baik & 59 & 56.2 & & & & \\
\hline \multirow{2}{*}{$\begin{array}{c}\text { Daya } \\
\text { tanggap }\end{array}$} & Baik & 46 & 43.8 & \multirow{2}{*}{8.11} & \multirow{2}{*}{1.700} & \multirow{2}{*}{3} & \multirow[t]{2}{*}{12} \\
\hline & Kurang Baik & 59 & 56.2 & & & & \\
\hline \multicolumn{2}{|c|}{ Total } & 105 & 100 & & & & \\
\hline
\end{tabular}

\section{PEMBAHASAN}

Menurut pendapat peneliti, dari pertanyaan yang berkaitan dengan keandalan yaitu petugas memberikan informasi tentang fasilitas yang tersedia mempunyai nilai poin terendah yaitu sebesar 169 , artinya responden tidak puas dalam pelayanan di unit rawat jalan karena petugas kurang memberikan informasi berkaitan dengan fasilitas yang dapat digunakan oleh dirinya dalam rangka pengobatan namun pada poin pernyataan petugas memberitahu dengan jelas tentang halhal yang dilarang dalam pengobatan
Anda responden merasa puas dengan terlihat nilai yang cukup tinggi yaitu sebesar 330 artinya responden cukup puas terhadap penjelasan yang diberikan oleh petugas sehubungan hal-hal yang berkaitan dengan larangan yang harus dipatuhi dalam kesembuhan dirinya. Pada Jaminan atau jaminan pada item pernyataan tentang petugas memberi perhatian terhadap keluhan yang anda rasakan dan petugas dapat menjawab pertanyaan tentang tindakan pengobatan yang diberikan kepada Anda mempunyai poin tertinggi yaitu 
sebesar 348 artinya responden cukup puas terhadap tindakan yang ditampilkan oleh petugas namun bertolak belakang dari hasil tersebut ternyata masih banyak responden yang merasa bahwa petugas kurang jujur dalam memberikan informasi tentang keadaan Anda dengan poin jawaban sebesar 135 artinya pasien masih merasa bahwa petugas tidak berterus terang dengan penyakit yang ada pada dirinya, ada informasi-informasi yang masih ditutupi oleh petugas.

Pada bukti fisik atau bukti fisik pada item pernyataan petugas memberi informasi tentang administrasi yang berlaku bagi pasien memiliki nilai poin terendah hal ini dimungkinkan karena memang petugas kesehatan tidak memiliki wewenang dalam hal administrasi sehingga informasi yang diberikan oleh petugas pun dirasa kurang cukup baik oleh pasien karena selama ini informasi yang berkaitan dengan administrasi dapat ditanyakan secara langsung kebagian administrasi.

Pada empati dari beberapa item pernyataan diketahui bahwa pada item pernyataan petugas memberikan informasi kepada Anda tentang segala tindakan pengobatan yang akan dilaksanakan memiliki poin terendah yaitu sebesar 160 poin hal ini dimungkinkan karena ada beberapa hal yang memang dapat dijelaskan oleh perawat dan ada yang tidak boleh di mana harus dokter yang secara langsung memberikan penjelasan sedangkan pasien merasa bahwa semua petugas kesehatan yang bertanggung jawab terhadap dirinya harus mengetahui dan dapat memberikan segala informasi berkaitan dengan pengobatan yang dijalaninya. Pada item pernyataan petugas sering menengok dan memeriksa keadaan Anda seperti mengukur tensi, suhu, nadi, pernapasan dan cairan infus dan pelayanan yang diberikan petugas tidak memandang pangkat/status tapi berdasarkan kondisi Anda memiliki nilai poin tertinggi hal ini dimungkinkan karena memang petugas harus mengedepankan kepentingan pasien dengan melihat kondisi pasien tanpa memandang status dan petugas juga harus memberikan pelayanan standar dalam pemeriksaan seperti melakukan pengukuran tanda-tanda vital.

Pada daya tanggap atau daya tanggap di item pernyataan petugas segera menangani Anda ketika di ruangan memiliki nilai poin tertinggi hal ini dikarenakan semua pasien yang datang ke ruangan memang segera ditangani sesuai dengan keluhan namun pada item pernyataan petugas membantu Anda untuk memperoleh obat memiliki nilai poin terendah, hal ini bisa terjadi karena obat yang ditebus oleh pasien memang ada di bagian apotek dan biasanya diambil sendiri oleh pasien tanpa diwakili oleh petugas sehingga terkadang pasien membutuhkan waktu yang cukup lama saat mengambil obat.

Pada Jaminan atau jaminan Petugas selalu memberi salam dan senyum ketika bertemu dengan Anda. Petugas teliti dan terampil dalam melaksanakan tindakan pengobatan kepada Anda. Petugas memberi perhatian terhadap keluhan yang Anda rasakan. Petugas dapat menjawab pertanyaan tentang tindakan pengobatan yang diberikan kepada Anda. Petugas jujur dalam memberikan informasi tentang keadaan Anda.

Pada bukti fisik atau daya tanggap Petugas memberi informasi tentang administrasi yang berlaku bagi pasien. Petugas selalu menjaga kebersihan dan kerapihan ruangan yang Anda tempati. Petugas menjaga kebersihan dan kesepian alat-alat kesehatan yang digunakan. Petugas menjaga kebersihan dan kelengkapan fasilitas kamar mandi dan toilet. Petugas selalu menjaga kerapian dan penampilannya. Pada empati Petugas memberikan informasi kepada Anda tentang segala tindakan pengobatan yang akan dilaksanakan. Petugas mudah ditemui dan dihubungi bila Anda membutuhkan. Petugas sering menengok dan memeriksa keadaan Anda seperti mengukur tensi, suhu, nadi, pernapasan dan cairan infus. 
Pelayanan yang diberikan petugas tidak memandang pangkat/status tapi berdasarkan kondisi Anda. Petugas perhatian dan memberi dukungan moril terhadap keadaan Anda (menanyakan dan berbincang-bincang tentang keadaan Anda).

Menurut Nursalam

menyatakan kepuasan pasien terjadi apabila apa yang menjadi kebutuhan, keinginan, kepuasan pasien dapat dipenuhi, maka pelanggan. Kepuasan pasien adalah perasaan senang atau puas bahwa produk atau jasa yang diterima telah sesuai atau melebihi kepuasan pasien. Kepuasan adalah persepsi terhadap produk atau jasa yang telah memenuhi kepuasannya.

Pada kepuasan pasien terlihat bahwa kemampuan dokter dan perawat untuk cepat tanggap menyelesaikan keluhan pasien dengan nilai poin mendapat nilai terendah baik pada kepuasan dan kepuasan artinya rumah sakit memerlukan evaluasi terhadap kemampuan dokter dan perawat untuk dapat cepat tanggap dalam menyelesaikan keluhan pasien sehingga dapat meningkatkan mutu pelayanan rumah sakit

Pada kepuasan terhadap dimensi jaminan yang memiliki nilai poin paling rendah adalah pengetahuan dan kemampuan dokter dan yang tertinggi adalah Ketrampilan para dokter, perawat dalam bekerja Sedangkan pada variabel kepuasan, pada pertanyaan jaminan berupa kesembuhan dan kepercayaan terhadap pelayanan mendapatkan poin terendah dibandingkan dengan yang lain hal ini disebabkan adanya faktor lain sehingga pasien tidak merasa mendapat jaminan berupa kesembuhan selain itu tidak ada kejelasan dari informasi tentang prognosis dari penyakit yang diderita membuat pasien merasa tidak ada jaminan kesembuhan dari pengobatan yang diberikan

Berdasarkan hasil penelitian ini dapat disimpulkan bahwa, persepsi bukti fisik berhubungan dengan kepuasan pasien karena bukti fisik yang diberikan oleh tenaga perawatan dan dokter masih ada yang dirasakan kurang baik atau memiliki makna negatif dari responden. Hasil deskripsi jawaban responden pada penelitian ini, komponen yang perlu ditingkatkan pada bukti fisik pelayanan asuhan di Rumah Sakit adalah kerapihan dan kebersihan tenaga perawatan dan dokter saat memberikan pelayanan, ruangan yang bersih, rapi, nyaman, dan tempat tidur yang sudah disiapkan dengan keadaan rapi dan bersih. Kebersihan dan kenyamanan ruangan rawat inap dapat langsung dirasakan oleh pasien dari awal pasien dirawat sampai keluar dari rumah sakit karena pasien juga membutuhkan sarana dan prasaran rumah sakit yang bersih dan nyaman.

Begitu pula dengan pelayanan pemeriksaan diagnosis dan tenaga perawatan dan dokter kesehatan antar hadap pasien yang cepat dan tepat terkadang dalam pemeriksaan terdapat keterlambatan sehubungan dengan pemeriksaan pasien lain yang juga membutuhkan waktu, sehingga pasien juga diharapkan dapat bersabar terhadap pelayanan yang diberikan, namun walaupun pelayanan pemeriksaan terkesan lambat namun yang diutamakan adalah ketepatan dalam mendiagnosis sehingga tenaga perawatan dan dokter kesehatan tidak salah dalam memberikan pengobatan bagi kesembuhan pasien.

Berdasarkan hasil penelitian ini maka dapat disimpulkan bahwa, kepuasan maupun ketidakpuasan pasien sangat berhubungan dengan persepsi empati pasien karena empati yang diberikan oleh tenaga perawatan dan dokter dapat dirasakan secara langsung oleh pasien dari awal pelayanan sampai akhir pelayanan asuhan yang pasien dapatkan di ruang rawat inap. Pada dasarnya setiap pasien ingin diperlakukan secara individu atau khusus, dengan demikian rasa empati tenaga perawatan dan dokter dalam memberikan asuhan merupakan alat utama dalam memenuhi kepuasan pasien akan perlakuan istimewa, sehingga 
terwujudlah kepuasan pasien terhadap pelayanan asuhan yang mereka terima

Kemampuan memberikan

pelayanan yang dijanjikan dengan segera, akurat, dan memuaskan. Hai ini berarti rumah sakit memberikan jasanya secara tepat semenjak saat pertama (right the first time). Selain itu juga berarti bahwa rumah sakit yang bersangkutan memenuhi janjinya, misalnya menyampaikan jasanya sesuai dengan jadwal yang disepakati. Dalam unsur ini, pemasar dituntut untuk menyediakan produk atau jasa yang handal. Produk atau jasa jangan sampai mengalami kerusakan atau kegagalan. Dengan kata lain, produk atau jasa tersebut harus selalu baik. Empati merupakan memberikan perhatian yang tulus dan bersifat individual atau pribadi yang diberikan kepada para kebutuhan para pasien.

\section{KESIMPULAN}

Rata-rata kepuasan pasien rawat jalan pada Kehandalan adalah 12.00 Pada Jaminan adalah 12.93 Pada Bukti fisik adalah 11,87 Pada Empathy adalah 12.78 Pada Responsivenes adalah 12.88 di unit rawat jalan memiliki nilai kepuasan terkecil pada Bukti fisik. Sebagian besar responden mengungkapkan kehandalan kurang baik yaitu sebanyak $59 \%$, jaminan kurang baik sebesar $58.1 \%$, bukti fisik baik sebanyak $59 \%$, empati kurang baik sebanyak $61 \%$ dan daya tanggap kurang baik sebanyak 54.3\%. Dapat disimpulkan bahwa dari kelima dimensi yang berkaitan dengan kepuasan tersebut diketahui bahwa aspek empati merupakan aspek yang paling banyak dengan kategori kurang baik.

Rata-rata kepuasan pasien rawat inap pada Kehandalan adalah 12.07. Pada Jaminan adalah 11.86. Pada Bukti fisik adalah 13.24. Pada Empathy adalah 12.12. Pada Responsivenes adalah 12.42.. Sebagian besar responden mengungkapkan kehandalan baik yaitu sebanyak $51.4 \%$, jaminan kurang baik sebesar $50.5 \%$, bukti fisik baik sebanyak $56.2 \%$, empati baik sebanyak $51.4 \%$ dan daya tanggap kurang baik sebanyak $50.5 \%$. dari kelima dimensi yang berkaitan dengan kepuasan tersebut diketahui bahwa aspek jaminan dan daya tangap merupakan aspek yang paling banyak dengan kategori kurang baik.

Rata-rata kepuasan pasien kamar operasi pada Kehandalan adalah 8.18. Pada Jaminan adalah 9,18. Pada Bukti fisik adalah 7,95. Pada Empathy adalah 8,00. Pada Responsivenes adalah 8,11 . Sebagian besar responden mengungkapkan kehandalan baik yaitu sebanyak $58.1 \%$, jaminan baik sebesar $62.9 \%$, bukti fisik baik sebanyak $65.7 \%$, empati kurang baik sebanyak $56.2 \%$ dan daya tanggap kurang baik sebanyak $56.2 \%$. berdasarkan table diatas dapat disimpulkan bahwa dari kelima dimensi yang berkaitan dengan kepuasan tersebut diketahui bahwa aspek empati dan daya tangap di unit kamar operasi kategori kurang baik.

Perbedaan kepuasan pada pasien di unit rawat inap sebesar $48.6 \%$ puas dan di unit rawat inap serta di kamar operasi masing-masing sebesar $54.3 \%$ puas. dapat disimpulkan bahwa dari ketiga ruangan tersebut, unit rawat inap merupakan unit dengan kepuasan pasien terendah jika dibandingkan dengan unit rawat jalan dan kamar operasi.

\section{DAFTAR PUSTAKA}

Azwar, Saipunin. (2016). Sikap Manusia: Teori Dan Pengukurannya. Pustaka Pelajar: Jakarta.

Dinas Kesehatan Kota Bandar Lampung. (2014). Profil Kesehatan Kota Bandar Lampung Tahun 2013. Lampung

Firmayasa, Agtovia. (2017). Pengaruh Kepuasan Terhadap Loyalitas Pasien Rawat Inap Pada Rumah Sakit Khusus-THT Bedah Kepala Leher Proklamasi Jakarta Pusat. Bina Sarana Informatika Jakarta

Hastono, Sutanto Priyo., (2016). Analisis Data Pada Bidang Kesehatan. Rajawali Pers: Jakarta. 
Hermanto, Dadang. (2010). Pengaruh Persepsi Mutu Pelayanan Kebidanan Terhadap Kepuasan Pasien Rawat Inap Kebidanan di RSUD Dr.H.Soemarno Sosroatmodjo Bulungan Kalimantan Timur Tahun2010. Universitas Diponegoro Semarang.

Kementrian Kesehatan Republik Indonesia. (2014). Pokok-Pokok Riset Kesehatan Dasar Lampung Tahun 2013. (diakses 13 Desember 2017 dari http//depkes.go.id).

Kementerian Kesehatan Republik Indonesia. (2016). Profil Kesehatan Indonesia 2015. Indonesia

Lestari, Suci. (2016). Pengaruh Kualitas Pelayanan Terhadap Kepuasan Pelanggan Pada Instalasi Farmasi Rumah Sakit Islam Siti Khadijah Palembang. UIN Raden Fatah Palembang

Manimaran S, Sindhya R, Venkateshwaran. (2010). A Study of Patients Expectation and Satisfaction in Dindigul Hospitals. Asian Journal Of Management Research.

Mangkunegara, A.A.Anwar Prabu. (2014). Manajemen sumber daya manusia perusahaan. PT Remaja Rodaska: Bandung

Notoatmodjo, Soekidjo. (2012). Metodologi Penelitian Kesehatan. Ed. Rev. Rineka Cipta: Jakarta

Nurdiana. (2017). Analisis Kepuasan Pasien Rawat Inap Di Rumah Sakit Umum Bahteramas Provinsi Sulawesi Tenggara. Universitas Halu ULEO Kendari

Nurhidayat, Alvan. (2013). Hubungan Mutu Pelayanan Keperawatan Dengan Tingkat Kepuasan Pasien Di Ruang Rawat Inap Klinik Harapan Bersama Ambulu Jember. S1 Keperawatan Fikes Universitas Muhammadiyah Jember.

Nursalam. (2016). Manajemen Keperawatan. Salemba Medika: Jakarta
Noor Azlinna Azizan \& Bahari Mohamed. (2013). The Effect of Perceived Service Quality On Patient Satisfaction At A Public Hospital In State of Pahang, Malaysia. Asian Journal of Social Science and Humanities Vol: 2, No: 3.

Pohan, Imbalo. (2013). Jaminan Mutu Layanan Kesehatan. EGC: Jakarta

Rahmawati, Alfi Febriana., Supriyanti Stefanus. (2013). Mutu Pelayanan Kesehatan Berdasarkan Dimensi Dabholkar di Ruang Rawat Inap Penyakit Dalam. Universitas Airlangga Surabaya

Rashid Al-Abri \& Amina Al-Balushi. (2014). Patients Satisfaction Survey As A Tool Toward Quality Improvement. Journal Nurse Care Quality, Vol: 16, No:4.

Riyanto, Agus. (2011). Aplikasi Metodologi Penelitian Kesehatan. Nuha Medika: Yogyakarta

Respati. (2015). Hubungan Mutu Pelayanan Kesehatan dengan Tingkat Kepuasan Pasien Rawat Inap di Puskesmas Halmahera Kota Semarang Tahun 2014. (diakses 17 Desember 2017 dari http://lib.unnes.ac.id/20257/1/64 11411220-S.pdf)

Rumah Sakit Bintang Amin Bandar Lampung . (2017). Profil Kesehatan Rumah Sakit Bintang Amin Bandar Lampung 2016

Rosita, Saragih, Arlina, Nurbaity, Raras, Sutatningsih. (2011). Pengaruh Mutu Pelayanan Kesehatan Terhadap Loyalitas Pasien Rumah Sakit Umum Herna Medan. (diakses 19 Desember 2017 Available From: http:// uda.ac.id /jurnal/ files/ tesisdesemberrosita.pdf) 